\title{
Investigation and research of Hui nationality medicine in Sino Arab
}

\author{
Economic and trade
}

\section{Huang Wei, Liao Zhaoyu}

School of economics and management Tarim University Xinjiang 843300 Alar City

Keywords: Hui nationality medicine; China; Arabian region; economic trade;

\begin{abstract}
Objective: to discuss and analyze the application and development of Hui nationality medicine in Sino Arab Economic and trade. Methods: to attend the 2016 Sino Arab Economic and Trade Forum cum CITIF will Arabia area some scholars, businessmen, politicians and some in the China area settled and engaged in the business work of fellow Muslims but also as the research object, a total of 200 people. This study investigated the awareness of Hui medicine in Arabic countries and regions by means of self-made Arabic Edition questionnaire survey. Results: a total of 200 questionnaires were issued and 200 were recovered. The effective rate of recovery was $100 \%$ (200/200). Hopi medicine awareness rate was $45 \%$, of which $90 \%$ of the staff is the content through participation in economic and Trade Forum China Argentina learned acupuncture; the most famous, accounted for $92 \%$, massage the most acceptable, accounting for $89 \%$; $64 \%$ people advocating the treatment of neck and leg disease, $58 \%$ of people think that physical fitness. $79 \%$ people can accept the use of Hui medicine ointment prescription in the treatment of diseases, $34 \%$ of people think that it is necessary to set up the Hui clinic in the countries and regions in the hospital, only 10\% people know the Hui medicine speciality in Ningxia Medical University, but 45\% of people are willing to understand. Conclusion: Hui medicine in Arabia national and regional awareness rate is low, but many people with acupuncture, massage and other Hui medical technology are full of interest, should increase the Hui medicine promotion efforts to promote Sino Arab friendship.

Hui medicine is an important part of medical treasure house of our country, is a unique medical civilization in China Hui people in thousands of years of history of the nation's outstanding medical knowledge and Islamic medicine are combined to create a. Hui medicine basic guiding ideology is "four", "17 true" Islamic medicine pathological basis of [1], the "Qi tonality" as the main rule is, in practice the process of combining relevant knowledge of traditional Chinese medicine, its application and development with a strong national colors and religious color, is a clinical study of diagnosis and treatment for [2] disease. As China's "Silk Road" of the development of our country and the Arabia area of economic and trade exchanges more closely, many countries of Arabia Muslim compatriots of Hui nationality in China Medical and pharmaceutical knowledge interest. In this regard, we have adopted the form of self-made questionnaires to identify and study the spread and application of Hui medicine in Sino Arab Economic and trade.
\end{abstract}

\section{Data and methods}

2016 CITIF and Arab Economic Trade Forum will be held during the period, to some scholars, businessmen and politicians in Arabia participants as the research object, and some in the area and settled Chinese Muslim compatriots also engaged in the business work as the research object, a total of 200 people. These included 117 males and 83 females, aged 23-72 years and mean age (46.33+ 10.24) years. Among 200 patients involved in the study, including Saudi Arabia 55 cases, Kuwait 
36 cases, Arabia United Nations 33 cases, Egypt 21 cases, Iran 20 cases, Yemen 19 cases, Bahrain 16 cases.

Special personnel are drawn up to form a questionnaire, and the exact contents are shown in table 1. The table is divided into Chinese version and the Arabic version of the two versions, including all personnel involved in the study received for the Arabic version, first fill in the basic information, including name, gender, nationality, age, type of work, and then one by one to answer the questions in the questionnaire. For those who have doubts, the organization of professional Arabia language staff in Arabic to explain patiently and communicate with them. The chinese version of the questionnaire for the data statistics, collation and summary use.

\begin{tabular}{|c|c|c|c|}
\hline Survey content & \multicolumn{3}{|c|}{ Evaluation situation } \\
\hline $\begin{array}{l}\text { 1. Do you know the Hui } \\
\text { nationality medicine? }\end{array}$ & A know (45\%) & $\begin{array}{l}\text { B don't know } \\
(55 \%)\end{array}$ & \\
\hline $\begin{array}{l}\text { 2.How do you understand the } \\
\text { Hui medicine? }\end{array}$ & $\begin{array}{l}\text { A Sino Arab } \\
\text { Economic and } \\
\text { Trade } \text { Forum } \\
(90 \%)\end{array}$ & B Internet (7\%) & $\begin{array}{l}\text { C listen to } \\
\text { others talk } \\
\text { about (3\%) }\end{array}$ \\
\hline $\begin{array}{l}\text { 3. Are you interested in Hui } \\
\text { medicine? }\end{array}$ & $\begin{array}{ll}\text { A } & \text { interest } \\
(72 \%) & \\
\end{array}$ & B general (22\%) & $\begin{array}{l}\text { C without } \\
\text { interest }(6 \%)\end{array}$ \\
\hline $\begin{array}{l}\text { 4. Do you know the Chinese } \\
\text { wolfberry in Ningxia? }\end{array}$ & A know (39\%) & $\begin{array}{l}\text { B don't know } \\
(61 \%)\end{array}$ & $\begin{array}{l}\text { C would like } \\
\text { to know } \\
(95 \%)\end{array}$ \\
\hline $\begin{array}{l}\text { 5. Do you know "eight bottles } \\
\text { of soup bottle"? }\end{array}$ & A know $(31 \%)$ & $\begin{array}{l}\text { B don't know } \\
(69 \%)\end{array}$ & $\begin{array}{l}\text { C would like } \\
\text { to know } \\
(88 \%)\end{array}$ \\
\hline $\begin{array}{l}\text { 6. What do you know about } \\
\text { the medicine in Hui } \\
\text { nationality medicine? }\end{array}$ & \multicolumn{3}{|c|}{$\begin{array}{l}\text { A acupuncture (92\%) B massage cupping (80\%) C } \\
(65 \%) \text { D (55\%) E acupuncture bloodletting therapy } \\
(40 \%)\end{array}$} \\
\hline $\begin{array}{l}\text { 7. Would you choose to use } \\
\text { the Hui medicine to treat the } \\
\text { diseases in your daily life? }\end{array}$ & A Yes $(33 \%)$ & B Not sure $(42 \%)$ & C No $(25 \%)$ \\
\hline $\begin{array}{l}\text { 8. Would you like to come to } \\
\text { Ningxia to use the Hui } \\
\text { medicine to treat the diseases } \\
\text { in your daily life? }\end{array}$ & A Yes $(15 \%)$ & $\begin{array}{l}\text { B Not sure } \\
(45 \%)\end{array}$ & C No $(40 \%)$ \\
\hline $\begin{array}{l}\text { 9. Would you like to go to the } \\
\text { area of Hui medicine for } \\
\text { treatment? }\end{array}$ & A Yes $(52 \%)$ & $\begin{array}{l}\text { B Not sure } \\
(39 \%)\end{array}$ & C No（9\%） \\
\hline $\begin{array}{l}\text { 10. After knowing the Hui } \\
\text { medicine, would you like to } \\
\text { recommend the Hui } \\
\text { nationality medicine to your } \\
\text { family or friends? }\end{array}$ & A Yes $(45 \%)$ & $\begin{array}{l}\text { B Not sure } \\
(16 \%)\end{array}$ & $\begin{array}{ll}\mathrm{C} & \text { No } \\
(39 \%) & \end{array}$ \\
\hline $\begin{array}{l}\text { 11.After understanding Hui } \\
\text { medicine, do you think Hui } \\
\text { medicine can be popularized } \\
\text { in your country and region? }\end{array}$ & A Yes $(59 \%)$ & B Not sure (21\%) & $\begin{array}{l}\text { C No } \\
(20 \%)\end{array}$ \\
\hline
\end{tabular}




\begin{tabular}{|c|c|c|c|}
\hline $\begin{array}{l}\text { 12. What diseases do you } \\
\text { think can be resolved by } \\
\text { receiving the treatment of Hui } \\
\text { medicine? }\end{array}$ & \multirow{2}{*}{\multicolumn{3}{|c|}{$\begin{array}{l}\text { A NSLP (64\%) Bstrongbody (58\%) C Gynecology, } \\
\text { male disease (36\%) } \\
\text { A acupuncture(60\%) B massage cupping (89\%) C } \\
(50 \%) \text { D (39\%) E acupuncture bloodletting therapy } \\
(23 \%)\end{array}$}} \\
\hline $\begin{array}{l}\text { 13. What kind of Hui therapy } \\
\text { do you accept? }\end{array}$ & & & \\
\hline $\begin{array}{l}\text { 14. Can you accept the } \\
\text { treatment of Hui medicine for } \\
\text { external use? }\end{array}$ & A Can $(79 \%)$ & B Cant (21\%) & \\
\hline $\begin{array}{l}\text { 15.Can you accept the } \\
\text { treatment of the Hui } \\
\text { nationality } \\
\text { decoction and pill? }\end{array}$ & A Can $(41 \%)$ & B Cant（59\%） & \\
\hline $\begin{array}{l}\text { 16.If there is no } \\
\text { communication problem, can } \\
\text { you accept Chinese Hui } \\
\text { doctors for medical treatment } \\
\text { in your country or region? }\end{array}$ & ACan $(75 \%)$ & B Cant (25\%) & \\
\hline $\begin{array}{l}\text { 17. Do you think it is } \\
\text { necessary to open a Hui clinic } \\
\text { in your country or region's } \\
\text { hospital? }\end{array}$ & A Yes (34\%) & B No $(66 \%)$ & \\
\hline $\begin{array}{l}\text { 18. Do you think it necessary } \\
\text { to set up the Hui major in } \\
\text { your country or region? }\end{array}$ & A Yes (52\%) & B No $(48 \%)$ & \\
\hline $\begin{array}{l}\text { 19. Do you know the Hui } \\
\text { medicine major of Ningxia } \\
\text { Medical University? }\end{array}$ & A Know（10\%） & $\begin{array}{l}\text { B don't know } \\
(90 \%)\end{array}$ & $\begin{array}{l}\text { C would } \\
\text { like to know } \\
(45 \%)\end{array}$ \\
\hline $\begin{array}{l}\text { 20.Would you like to } \\
\text { introduce your family or } \\
\text { friends to study Hui medicine } \\
\text { in Ningxia? }\end{array}$ & A Yes $(37 \%)$ & B No（63\%） & \\
\hline
\end{tabular}

Table 1 current situation of Hui nationality medicine in Sino Arab Economic and trade

\section{Result}

In this survey, a total of 200 Arabic questionnaires were issued and 200 were recovered, with an applicable recovery rate of $100 \%$ (200/200). Through statistical analysis of specialized personnel, 200 subjects participated in this survey, 90 people have heard of Hui medicine, accounting for 45\%, of which $90 \%$ of the staff is the content through participation in economic and Trade Forum China Argentina learned; $72 \%$ people are interested in Hui medicine, 39\% of the people to understand Ningxia mulberry, 31\% of the people know about "eight bottles of soup.". In the Hui medicine therapy, acupuncture is the most famous, accounting for $92 \%$, followed by massage and cupping therapy; while in the Hui acceptable, ranked first is accounted for $89 \%$, followed by massage, acupuncture and cupping; in the treatment of disease, $64 \%$ people advocate for neck and back 
disease treatment, 58\% people think that physical fitness. 33\% of people choose to use medicines to treat diseases of Hui daily, willing to come to Ningxia for treatment of 30 people, accounting for 15\%; 52\% people are willing to accept the medical treatment of Hui nationality in the residence, would like to recommend to your family and friends for $45 \%$, think Hui medicine can be spread in countries and regions accounted for 59\% of Arabia.

$79 \%$ people can accept the use of Hui medicine ointment prescription in the treatment of disease, 41\% people can accept the Hui Chinese medicine decoction and pill treatment, 75\% people fluent in Arabic Chinese Hui physician to the countries and regions in the medical treatment. 34\% of the people think it is necessary to open the Hui nationality clinic in the hospitals of this country and region, and 52\% of them think it necessary to open this subject in the universities of this country or region. Only $10 \%$ knew Ningxia Hui Medical University, but $45 \%$ of them would like to know; $37 \%$ would recommend to family and friends to study medicinal knowledge of Hui nationality in Ningxia. Precise data are shown in table 1.

\section{Discussion}

Chinese Hui medicine as an important part of Chinese medicine, is an excellent product Chinese medicine and Western medicine integration, both of the national medical technology characteristic, but also influenced by other national medicine, the medicine in the history of the development Chinese made a significant contribution to [3]. As the largest gathering place of Hui nationality in China, Ningxia is the birthplace of the emergence and development of Hui medicine, and has great practical value. [4]. With the development of reform and opening up and China "Silk Road", "The Belt and Road" development, between countries and regions China and Arabia economic and trade are closely linked, many countries and regions of Arabia in the process of contact with the Muslim compatriots in Ningxia have a strong interest in Ningxia medicine.

In this study, through the investigation and analysis of Arabia area to participate in the 2016 Sino Arab Economic and Trade Forum cum CITIF will be part of the scholars, businessmen, politicians and some in the Chinese area settled and engaged in the business work of Muslim compatriots, found that the rate was only $45 \%$ and $90 \%$ of them have known Hui medicine, the staff is the content through in the economic and Trade Forum learned, with the existing literature data compared to [5], the survey results showed that Hui medicine in Arabia national awareness has been enhanced, but the effect is still not ideal, so our Hui medicine promotion efforts have to be strengthened. In Hui medicine technology, acupuncture is most famous, accounted for 92\%, massage the most acceptable, accounting for 89\%; 64\% people advocating the treatment of neck and leg disease, $58 \%$ of people consider that physical fitness. This is mainly because the countries and regions in Arabia are widely spread and application of a Hijamah [6] with bloodletting therapy. The Hui medicine technology in acupuncture is very similar to that in the Arabia area and is generally recognized and accepted by people. Only 39\% of the people of Ningxia mulberry, 31\% of the people know about "eight bottles of soup." this may be because Arabia countries and regions rarely use traditional Chinese medicine decoction, and many countries of Chinese herbal medicine registration and management have very strict laws and regulations, hindered the development of the Chinese medicine formulations. At the same time, it reminds us that with the current Sino Arab Economic and trade forum, we should also make great efforts to publicize the knowledge and technology of Hui nationality medicine so as to achieve the effect of popularizing it.

In summary, Hui medicine in Arabia national and regional awareness rate is low, but many people with acupuncture, massage and other Hui medical technology is full of interest, should increase the Hui medicine promotion efforts to promote Sino Arab friendship. 


\section{References:}

[1] Hargreaves S, Friedland J S, Gothard P, et al. Impact on and use of health services by international migrants: questionnaire survey of inner city London A\&E attenders[J]. BMC Health Services Research, 2006, 6(1):153.

[2] Ning Y, Yunfeng L, Liu Y, et al. Study on construction of nursing system of Hui nationality culture based on national customs and habits[J]. Chinese General Practice Nursing, 2016.

[3] Jiang M, Qin Y. Current Situation Investigation and Countermeasures of School Sports Area of Hui nationality- - Taking Hui Township of Pingliang City as an Example[J]. Hubei Sports Science, 2015.

[4] Wang Y, Guang-Li M I, Bao-Ling L I, et al. Survey and analysis on self-management behaviors in Hui nationality patients with type 2 diabetes mellitus[J]. Modern Preventive Medicine, 2016.

[5] Zhang H, University N. The Overall Construction of the Historical and Cultural Research of the Hui People from the Space Perspective[J]. Social Sciences in Ningxia, 2016.

[6] Wang W, Hui Q. A Review of Religious Belief of Hui Nationality in Xi-Hai-Gu Areas of Ningxia[J]. Journal of Ethnic Art, 2016.

Author: Huang Wei (1990-), female (Han), Xinjiang alar city, postgraduate, historical cognition, religious understanding, cultural communication and tourism development and main research fields of the Silk Road of Western culture. Correspondence to the author: Liao Zhaoyu, male, Professor, (1970 -), the research direction is the history of the Western Silk Road culture, religious understanding, cultural communication and tourism development and other fields. The subject currently under discussion is National Science and technology support project:

Construction and application of integrated tourism service system of Tarim non heritage culture (serial number: 2013BAH27F00)

Humanities and social science research project of Ministry of Education: digital research and inheritance of Huaxia cultural resources in Central Plains of Xinjiang (13XJJA770001)

National Soft Science Research Project: investigation and digitization of Huaxia Culture Resources in Central Tarim Basin (2013GXS4D157)

Project of the National People's Congress: the strategy of multi national culture and the westward movement of the Tarim (2012-GM-055)

Corps Social Science Foundation Project: the evolution track of the Tarim cultural heritage and ethnic groups (number: 10BTYB20) and so on.

通讯地址：新疆阿拉尔市塔里木大学经济管理学院；黄玮;联系方式: 18083969818. 